кандидат історичних наук, доцент кафедри міжнародних відносин Київського національного університету культури і мистецттв

(Україна, Київ) nakonechniy.ua@gmail.com

\title{
ТРАГЕДІЯ УКРАЇНЦІВ ЗАКЕРЗОННЯ (АКЦІЯ «ВІСЛА» НА СТОРІНКАХ ЖУРНАЛУ «ЛЕМКІВЩИНА»)
}

\begin{abstract}
У статті досліджено проблему висвітлення акиії «Вісла» на сторінках журналу «Лемківщина». 3 'ясовано, щуо иій темі було присвячено найбільшу кількість різнопланових матеріалів (наукові розвідки, публіцистичні виступи, художні твори). Підсумовано, щз журнал став літописом трагедії лемківського світу, виконуючи функцію плекання історичної пам'яті та застереження елітам Східної Європи уникати трагічних помилок минулого.
\end{abstract}

Ключові слова: «Лемківщина», акиія «Вісла», польсько-украӥнські стосунки, історична пам'ять, лемкознавство, депортаиії, українська діаспора.

Jim. 26.

Volodymyr NAKONECHNYJ, PhD (History), Associate Professor at the Department of International Relationships of Kyiv National University of Culture and Arts (Ukraine, Kyiv) nakonechniy.ua@gmail.com

\section{TRAGEDY OF UKRAINIANS OF TRANSCURZONIA (ACT «VISLA» ON THE PAGES of MAGAZINE «LEMKIVSHCHYNA»)}

The article deals with the problem of coverage of the "Wisla» campaign on the pages of the «Lemkivshchyna» magazine. It was discovered that this topic was devoted to the largest number of diverse materials (scientific article, journalistic performances, belle-letters works). It has been investigated that the greatest publication was devoted to the commemoration of the 35th and 40th anniversary of the tragedy of the Ukrainians' Zakerzonia. It has been emphasized on the prominent role of the "Lemkivshchyna» editorial board in launching the academic discourse of the «Wisla» campaign.

It was clarified that the «Lemkivshchyna» editorial board emphasized on the importance of collecting as much of the documents, evidences and facts about the events of 1947 as possible. For the purpose of this, the need to conduct interviews with the surviving witnesses on the destruction of Lemkivshchyna and store them in the form of video records for the archives of the Lemkivshchyna Research Foundation is vital. There was an appeal to collect the biggest amount of possible comparative photo material from the ancient (from before 1947) times and about the actual state of the same territories of Lemkivshchyna. There was discussion about the need to create scholarships for researchers who would like to work on the 1947th issue. At the same time, it was stressed on the necessity to publish all these works not only in Ukrainian, but also in world languages, mainly English. The idea was to find the historian of world glory who would write a monograph on these years in Lemkivshchyna. The "Lemkivshchyna" editors also appealed to Ukrainian patrons from the free world to raise funds for the funding of studies, research, scholarships and the publication of relevant materials on 1947, as well as to financially help those who want to return to their ancestral lands.

There has been pointed out the importance of humanistic pathos devoted to the resettlement of materials. It was in the reasoned deconstruction of stereotypes imposed on Ukrainians regarding their history, culture and national character. The conclusions states that the publications of «Lemkivshchyna» worked out as a relay race, forcing fraternal peoples to come to a joint assessment of the tragedies of the past in order to prevent them from happening in the future.

Key words: «Lemkivshchyna», «Wisla» campaign, Polish-Ukrainian relations, historical memory, lemcology, deportations, Ukrainian diaspora.

Ref. 26. 
кандидат исторических наук, доцент кафедры международных отношений Киевского национального университета культуры и искусств

(Украина, Киев) nakonechniy.ua@gmail.com

\title{
ТРАГЕДИЯ УКРАИНЦЕВ ЗАКЕРЗОНЬЯ (АКЦИЯ «ВИСЛА» НА СТРАНИЦАХ ЖУРНАЛА «ЛЕМКІВЩИНА»)
}

\begin{abstract}
В статье исследовано проблему освещуения акции «Висла» на страницах журнала «Лемківщуина». Выяснено, что этой теме было посвящено наибольшее количество разноплановых материалов (научные статьи, публицистические выступления, художественные произведения). Доказано, что журнал стал летописью трагедии лемковского мира, выполняя функцию трансляции исторической памяти и предупреждения элитам Восточной Европы избегать трагических ошибок прошлого.
\end{abstract}

Ключевые слова: «Лемківщина», акция «Висла», польско-украинские отношения, историческая память, лемковедение, депортации, украинская диаспора.

Лит. 26.

Постановка проблеми. Цьогорічне широке відзначення 70-ліття трагедії української меншини у Польщі вкотре привернуло увагу широких кіл громадськості та представників експертного середовища до цієї трагічної сторінки українсько-польських взаємин. При цьому особливої актуальності набуває історіографічний аспект проблеми - намагання реконструювати витоки академічної рефлексії над подіями 1947 р. I тут увагу лемкознавців традиційно привертає найбільш авторитетна в діаспорі медійна трибуна українців Закерзоння - журнал «Лемківщина». Саме на сторінках цього видання, що тривалий час було єдиним друкованим органом лемків у вільному світі, було ініційовано всебічне дослідження акції «Вісла». На жаль, цей аспект лемкознавчої історіографії надалі залишається практично недослідженим.

Аналіз останніх досліджень. Журнал «Лемківщина» тривалий час перебуває у полі зору дослідників русинського субетносу. Покликання на опубліковані в ньому матеріали чи згадки про видання містяться у працях багатьох сучасних лемкознавців [17]. Водночас досі не було спеціальної спроби відтворити евристичний потенціал опублікованих на шпальтах «Лемківщини» дописів для реконструкції перебігу переселенської акції 1947 р., відомої в історіографії під назвою «Вісла». Цим і зумовлена актуальність нашого дослідження. При цьому ми сфокусуємося на діаспорному періоді існування журналу, коли потреба трансляції травмованої історичної пам'яті лемків мала особливу значущість для української нації.

Мета статті полягає у комплексному дослідженні представлених на сторінках «Лемківщини» матеріалів, присвячених акції «Вісла».

Виклад основного матеріалу. Збереження та трансляція пам'яті про найбільшу трагедію лемківського субетносу, як спеціальне завдання «Лемківщини», було вказане вже у зверненні редакційної колегії до своїх читачів у першому числі журналу за 1979 р. Зокрема, у ньому наголошувалося на потребі боротьби «з ворожими польськими $[. .$.$] облудними ідеями»- себто намаганнями$ шовіністично налаштованої частини польського політикуму представити переселенські акції як природну відплату за діяльність на лемківських теренах підрозділів Української повстанської армії $[6,1]$. Іншою важливою метою видавці журналу вважали контрпропаганду, як необхідну реакцію на ідейні диверсії з боку польських політиків різних партій, що об'єдналися у пориві «защіплювати почуття меншовартости серед української молоді і підсичувати традиційну польську погорду і ненависть до всього що українське», тим самим профануючи трагедію лемківського геноциду $[6,1]$.

3 огляду на щойно згадані завдання, вже в перших числах «Лемківщини» почали з'являтися різнопланові матеріали про акцію «Вісла», в яких було артикульовано потребу всебічного переосмислення трагедії українців Закерзоння. Зручним приводом для такого обговорення стало відзначення 35-ліття переселенської акції, котре лемківські організації у вільному світі планували провести в 1982 р. До цієї важливої події готувалася й «Лемківщина», визначаючи коло питань, які слід було обговорити та з'ясувати насамперед [12; 14]. 
До таких найбільш спотворених польською пропагандою сюжетів акції «Вісла» належала теза про ії відплатний характер. Йшлося про те, що, не маючи можливості збройно подолати опір УПА, польський комуністичний режим, вирішивши позбавити повстанський рух економічної бази, був нібито вимушений насильницьки переселити українське населення Лемківщини на новоприєднані до Польщі колишні німецькі землі (в термінах польської історіографії - «Ziemie Odzyskane»). Уперше на спекулятивний характер такого пояснення звернув увагу Іван Лико у спеціальній студії «Ще до питання - УПА і Лемківщина». Він цілком виправдано розпочав розгляд проблеми у тривалій історичній ґенезі, переконливо демонструючи, що польська влада у всі історичні періоди намагалася денаціоналізувати лемківський субетнос або за будь-яку ціну витіснити його з природного ареалу розселення. Це, слушно твердить автор, викликало зрозумілий спротив українського населення, котре від давніх часів стихійно організовувало загони захисників [13, 3-4]. У роки Другої світової війни такими оборонцями краю стали воїни УПА. Тож правда полягає в тому, що лише завдяки їхньому захисту місцеве населення не було винищене в роки воєнного лихоліття зайдами різних кольорів. Підсумовуючи свої розважання, автор твердить: «Польща - біла чи червона, аристократична, демократична чи комуністична, аж до наших часів не зуміла вписатися в історію як добрий сусід України. Бо сама назва політичного устрою не змінювала суті настанови поляків до українців у загальному, а зокрема до найбільше й найдовше поневоленого їхнього лемківського племени. Насильне виселення всіх лемків і українців інших частин Закерзоння було й залишилося особливо жорстоким актом варварства» $[11,1]$.

Сформульовані I. Лико тези стали відправними у наступних публікаціях, що фокусувалися на проблемі взаємопов'язаності повстанського руху з переселенськими акціями. Вповні виправдано було звернуто увагу на той переконливий факт, що задокументовані плани поляків виселити українців Закерзоння є значно більш ранніми, аніж поява перших загонів УПА на лемківських теренах. Особлива активність повстанського руху на Закерзонні якраз і була спровокована гвалтовними діями польських воєнних загонів, котрі, за взірцем фашистського режиму, втілювали в життя плани «остаточного вирішення» присутності українців на їхніх історичних землях.

Важливий методологічний характер мала проблема темпорального окреслення трагедії. Саме тоді лемкознавці вперше звернули увагу на той факт, що акція «Вісла» стала фактично лише фінальним акордом драми українців Закерзоння. Йшлося про те, що перші кроки з масового вигнання лемків були здійснені вже в 1944 р., коли лінія фронту посунулася на захід. За спиною українців, радянська, польська та чеська влади домовилися про «переміщення» етнічних груп, насамперед українців, з їхнього історичного ареалу розселення. При цьому декларувався мирний характер такого переселення, але його практика набула терористичних форм, котрі мали всі ознаки геноциду.

Інше вагоме питання концептуального характеру, на яке вперше звернули увагу автори «Лемківщини», полягало в дефінітивному окресленні вчиненого поляками злочину проти людяності. Використовуючи тогочасну міжнародну правову документацію, лемкознавці цілком аргументовано вказали на геноцидний характер проведеної переселенської акції. При цьому, що важливо, було відзначено подібність терористичних практик фашистського, більшовицького та польського комуністичного режимів у ліквідації мирного населення. Уперше на сторінках журналу про це написав Василь Пасічняк. «Весною 1947 почалася остання кінцева переселенча акція - акція «Вісла», яка своєю жорстокістю та розмірами перевершила всі попередні переселення, - твердить автор. - Виселювано все українське населення - Закерзоння стало безлюдною пустелею на довгі роки. Жертви українського населення були великі. Але без боротьби УПА вони були б ще більші, бо ворог плянував знищити поголовно всіх українців. [...] Отже Варшава на спілку з Москвою доконали геноцид українського населення, знищивши 280,000 українців Закерзоння, цебто одну четверту частину всього населення. Переселенча акція «Вісла» була подібною до давного татарського ясиру» $[18,4]$.

Інтерпретативну логіку В. Пасічняка розвинув доктор Іван Гвозда [5]. Він звернув увагу читачів на той очевидний факт, що польська влада упосліджувала українців протягом багатьох століть, тож дії комуністичних варварів постають лише логічним продовженням вчинків їхніх історичних попередників. Модерна комуністична Польща, твердить дослідник, по-варварськи чинить проти 
української меншості в своїй країні. Облави на лемківське населення і його погроми німецькими фашистами під час окупації України, наголошує І. Гвозда, зовсім не відрізнялися від злочинних погромів комуністичної Польщі в час її влади над цими територіями: i ті, й інші грабували українські села, гвалтували жінок, палили хати, вбивали дітей. А в 1947 р. під час акції «Вісла» військо комуністичної Польщі, в уже мирний повоєнний час, гнало в коров'ячі вагони безборонне українське населення і відсилало його до концентраційного табору в Яворжні чи на заслання у північно-західні понімецькі землі Польщі. Проводячи історичні паралелі, дослідник вказує: «Зовсім подібно до асирійської практики виселень повелися поляки з українцями в 1947 р. - їх виселили, а на опустілі українські землі насадили польський елемент» $[5,4]$.

Змальовуючи правдиву трагедію своїх земляків під комуністичним режимом, І. Гвозда звертає увагу на те, що вже третину століття тримає Польща українське населення на засланні. Тож безневинно карається вже не одне покоління у час, коли цивілізоване людство видало чимало міжнародних актів, у яких зафіксовані людські права, втім, і права меншостей; коли відбулося чимало міжнародних конференцій, які засудили модерну нацистську політику супроти національних меншин. Чимало договорів в справі людських прав, включно із гельсінською угодою, Польща

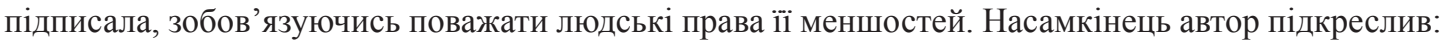
«Окремі цивілізовані країни західних демократій ухвалюють нові, чи змінюють старі закони й конституції, щоб дати своїм громадянам якнайбільше нагоди користуватися людськими правами у власних країнах, чи й поза межами власних держав. Більше й більше шириться переконання, що підставою миру в світі можуть бути тільки визнані й шановані людські права. Бо рівень визнання прав людини й громадянина $є$ зрештою й критерієм, яким муситься міряти рівень цивілізованості суспільств чи держав» $[5,5]$.

Ще однією новаторською, за своєю постановкою, проблемою, обговорення якої ініціювала редколегія «Лемківщини», стало обрахування прямих та відкладених у часі втрат, котрих зазнало українське населення Закерзоння внаслідок гвалтовних переселенських акцій. Уперше до цієї проблеми звернувся Василь Бородач у цікавому аналітичному дослідженні. Він вказав на проблеми, з котрими стикається дослідник згаданого питання, водночас аргументовано довівши, що жоден інший народ у повоєнній Свропі не зазнав таких руйнувань у матеріальному, біологічному та духовному вимірах своєї екзистенції. «По літах нищівного польсько-большевицького наїзду на терени українських західних земель і пізнішого примусового виселення українського населення 3 цього регіону, - наголосив автор, - сьогодні $є$ неможливим подати докладні наші матеріальні втрати в грошах. Неможливим є теж подати докладне число жертв українського населення, яке вимордували люди польського середовища та всі ці, яким доручено переводити в життя цю кари гідну акцію, що ії звали чогось «добровільним виселенням»» [4, 14].

Завдяки організаційним ініціативам редколегії «Лемківщини», 1982-й рік ввійшов до історії лемкознавства багатьма меморіальними та академічними заходами. На них звучали доповіді науковців і оповідання сучасників переселенських акцій, котрі одностайно закликали поглибити вивчення цієї трагедії українства, щоб не дати шансу на її повторення у майбутньому. Нагадуючи модерним варварам про їхній злочин, американські лемки проводили численні протестні акції під польськими амбасадами. Саме завдяки журналу, сьогодні можемо дізнатися про перебіг і різноплановість присвячених роковинам подій. Більшість 3 них були організовані з ініціативи крайових управ Об’єднання лемків Канади і США [3; 16; 20].

Успішна практика привернення уваги лемків та, зрештою, всього українства до подій акції «Вісла», стимульованих відзначенням 35-ліття цієї трагедії, стала добрим прикладом підготовки до меморіальних подій у 1987 р. Зауважимо, що це було найбільш масштабне вшанування пам'яті жертв геноциду українців Закерзоння до здобуття Україною незалежності. До його підготовки редколегія журналу «Лемківщина» взялася заздалегідь. Ще в першому числі за 1987 р. було опубліковано редакційну статтю під характерною назвою «40 літ тому...», де містилося обгрунтування пріоритетів меморіального року. Вже в цій статті був наведений узагальнювальний погляд на трагедію повоєнного українства: «1947... Сорок літ тому, 2 роки після закінчення Другої світової війни увесь світ приходив до нормального життя. Не було суджено почати нове життя тільки тим найдалі на захід висуненим віткам української землі - Лемківщині, Засянні та Холмщині. 
Населення тих земель зазнало чи не найгіршого знищення за останніх 700 літ свого існування. Союз СРСР, Польщі та Чехословаччини, протягом короткого часу перемінив цю квітучу країну на безлюдну пустиню» $[1,1]$.

3 огляду на сказане, наголошували редактори, в сорокаліття трагедії українських земель Закерзоння, обов'язком закордонних українців є: «не забути кривд нанесених нашим батькам, матер'ям, братам і сестрам у тих жорстоких часах; ширити правду про ті терпіння нашого народу серед інших народів світу, на місцях нашого поселення; нести моральну і матеріальну поміч тим, які ще осталися живими на батьківській землі; дати їм підтримку у їхній боротьбі за свої слушні права всіми можливими засобами; допомогти їм, чи їх дітям вернутися на прадідівські землі, що 3 них їх насильно виселено» [1, 1]. 3 метою реалізації визначених завдань, журнал збагатився тематичною рубрикою «40-ліття трагедії виселення». Також, починаючи 3 першого числа, кожен наступний випуск журналу «Лемківщина» протягом меморіального року був присвячений сорокаліттю трагедії української землі.

Організаційні аспекти відзначення сорокаліття акції «Вісла» було окреслено в іншій редакційній статті «Чи будемо готові?». Передовсім тут було запропоноване гасло, що об'єднувало всі академічні та меморіальні заходи: «Ми про Вас не забули і старалися, щоб Ваші терпіння і жертви життя та крові були задокументовані на віки» $[25,2]$. Далі в статті йшлося про добре продуману програму, реалізація котрої мала наблизити цивілізований світ до розуміння глибини трагедії українців Закерзоння. Відзначимо надзвичайно високий академізм цієї програми, більшість складових котрої й по сьогодні можуть вважатися важливими орієнтирами для дослідників акції «Вісла».

Насамперед редколегія «Лемківщини» наголосила на важливості потреби зібрати якнайбільше документів, доказів та фактів про події 1947 року. 3 цією метою вказувалося на необхідність зробити інтерв’ю-розмови з уцілілими свідками знищення Лемківщини, награти їх на відеоносії для архіву Фундації Дослідження Лемківщини. Був кинутий заклик зібрати якнайбільше порівняльного фотоматеріалу з давніх (з-перед 1947 р.) часів та актуального стану тих самих теренів Лемківщини. Звертаючи увагу на важливості цієї всебічності документації, наголошувалося: «Ворожі нам сили нищуть всі можливі докази хто жив на тій землі. Тому вони перевертають хрести на цвинтарях та придорожні каплички, де написи на них доказують, що там жили колись українці» $[25,2]$.

Далі йшлося про потребу створити стипендіальні фонди для молодих дослідників, як на еміграції, так і у Польщі чи Україні, які хотіли б працювати над питанням 1947 року. При цьому наголошувалося на необхідності видати всі ці праці не тільки українською, але і світовими мовами, головно англійською. Висувалася також цікава ідея знайти світової слави історика, який написав би монографію про ці роки на Лемківщині. В згаданій статті містився особливий заклик до українських меценатів з вільного світу зібрати відповідні фонди для фінансування дослідів, студій, стипендій та на видання відповідних матеріалів про 1947 рік, а також для того, щоби матеріально допомогти тим, хто хоче повернутися на свої прадідівські землі. У підсумку цієї важливої для розуміння поступу модерного лемкознавства статті йшлося: «Якщо ми над тим зачнемо працювати вже нині, прийдемо в 1997 році відзначувати 50-ліття трагічних подій на Лемківщині 3 почуттям частинного виконання свого обов'язку перед нашими рідними, що за святу прадідну віру і за свій нарід пронесли знищення, наруги, а той смерть» $[25,2]$.

Якщо організаційно відзначення сорокаліття акції «Вісла» випало значно більш насичено, аніж попереднє, то в концептуальному плані воно стало продовженням і поглибленням оцінок, що прозвучали в 1982 р. Так, у лемкознавчій літературі остаточно усталилася геноцидна оптика при оцінці здійснених польськими комуністами переселенських акцій. У багатьох публікаціях одностайно наголошувалося, що йдеться про «найбільш трагічну акцію народовбивства Лемківщини та всього українського населення за лінією Керзона» $[9,2 ; 26,1]$, а також «найганебніший злочин супроти частини українського народу на українських західних землях» $[8,2]$.

Також подальшої деконструкції зазнав міф про відплатний характер акції «Вісла», iї позірну зумовленість активністю партизанського руху на лемківських теренах, на чому тривалий час спекулювала польська комуністична пропаганда. Автори журналу вказували на потребі вивчення 
проблеми в генезі та твердили, що йдеться про серію переселенських акцій, розпочатих в 1944 р., тоді як в 1947 р. лише «запала занавіса останнього акту драми» [8, 3]. Отож, цілком невиправдано пов'язувати дії УПА та польських комуністів: «Трагедія Лемківщини і всього Закерзоння не була спричинена дією УПА, це був лише претекст до введення в життя дуже давніх задумів польського шовіністичного табору - фізичного знищення української Людини» $[8,3]$.

Зрештою, логічно твердили лемкознавці, якщо дії УПА на Закерзонні були причиною насильного виселення українців, то які причини існували для виправдання польського варварства супроти білоруського населення? Адже поляки вогнем знищили цілі білоруські села та винищили багато людей, про що писала західна преса, документуючи ці прояви варварства. Причини лемківського і всього Закерзоння трагедії, твердили автори «Лемківщини», слід шукати в традиційній польській політиці ліквідації українства: насильна полонізація за активної участі католицького духовенства сягає початків панування поляків ще в Русі. «Минали роки і століття, мінялись королі і уряди, але польська політика у відношенні до українського народу - твердив Іван Лико, залишилась незмінною до сьогоднішнього дня. Всі можливі середники панування спрямовано в минулому і спрямовується зараз на розгар і утрівалення серед польського народу шовінізму проти русина-українця, як істоти нижчої за поляка» $[8,3]$.

Важливою ініціативою журналу «Лемківщина» стало збирання матеріалів усної історії про акцію «Вісла». Зі сторінок журналу було кинуто клич до живих свідків трагедії поділитися власним болісним досвідом насильницького вигнання з рідних осель. Завдяки цій ініціативі вдалося створити солідний корпус мемуарних джерел, в якому був задокументований приватний вимір трагедії українців Закерзоння. Насиченою фактографічністю відрізнялися оповіді Ярослави Філь [23], Марти Феш [22] та Дмитра Цяпки [24].

Цікавою специфікою журналу «Лемківщина» була художньо-поетична складова його змісту. Редактори часопису намагалися донести важливі сторінки минулого українців Закерзоння через візуальні та поетичні образи. Не винятком тут стали і події лемківського геноциду. Так, зі сторінок журналу на читача дивляться поруйновані загарбниками громадські та сакральні споруди, понищені витвори церковного й ужиткового мистецтва. Біль лемків від насильного вигнання 3 рідних осель променіє й у багатьох віршах та піснях, котрими свідки подій ділилися зі своїми сучасниками. Особливою експресією художньої образності були позначені, приміром, твори отця Ярослава Ждинського [7], Юлії Саноцької [21] та Бориса Лемківського [10].

Пік обговорення повоєнної трагедії лемків, що припав на останню третину 1980-х рр., збігся у часі $з$ демократичними перетвореннями у самій Польщі. Демократична опозиція комуністичному режиму, об’єднана у лавах «Солідарності», визнавала потребу примирення поляків з національними меншинами, насамперед 3 українською. Першим кроком до цього стало визнання злочинності подій 1947 р. Польські інтелектуали почали показувати насильницький характер переселенських акцій, покладаючи вину на комуністичну владу [2, 2-4]. Врешті, на своєму історичному засіданні 3 серпня 1990 р. польський сенат засудив акцію «Вісла». У постанові було піддано засудженню принцип колективної відповідальності, котрим керувався польський комуністичний режим, виправдовуючи здійснюваний геноцид [19].

Напередодні української незалежності більшість польських інтелектуалів, захоплених ідеями міжнаціонального консенсусу Єжи Гедройця та паризької «Культури», визнали потребу примирення з українською меншиною ціною визнання вини та взаємопрощення. Як прояв цієї тенденції, «Лемківщина» опублікувала допис знакового польського опозиціонера Адама Міхніка, слова якого стали своєрідним «вірую» для тогочасних демократів: «Сьогодні стоїмо супроти нової фази польсько-української дебати, будем розмовляти без комплексів і без цензурного «кнебля» - вільні 3 вільними, рівні з рівними. Одною з тем, яких не дасться обминути є справа операції «Вісла». Від правди втекти не дасться. [...] Відповідальність за виселення українського населення паде на комуністичну владу. Це належить ствердити, резигнуючи в цьому моменті з рахунку кривд [...]. Ми винні це жертвам злочину, нашим дітям, самим собі» $[15,5]$.

Висновки. Проведений аналіз переконливо демонструє визначну роль редколегії «Лемківщини» у започаткуванні академічного дискурсу акції «Вісла». Різноплановість опублікованих на сторінках журналу матеріалів (наукові розвідки, публіцистичні виступи, художні твори) покли- 
кала до життя нові практики осмислення геноциду українців. Насамперед вкажемо на ініціативу журналу з публікації усних джерел. Важливим був і гуманістичний пафос присвячених переселенській акції матеріалів. Він полягав в аргументованій деконструкції нав'язаних українцям стереотипів щодо їх історії, культури та національного характеру. Загалом же, опрацьовані публікації «Лемківщини» постають як своєрідна естафета пам'яті, змушуючи братні народи дійти спільної оцінки трагедій минулого з метою їх запобігання в майбутньому.

\section{СПИСОК ВИКОРИСТАНИХ ДЖЕРЕЛ І ЛІТЕРАТУРИ}

1. 40 літ тому... // Лемківщина. - 1987. - Ч. 1. - С. 1.

2. Акція «Вісла» - Як розпалено ненависть. 3 істориком Евгеном Місилом розмовляє Жената Семпріх // Лемківщина. - 1990. - Ч. 4. - С. 2-4.

3. Американська преса 1948 року про трагедію Закерзоння // Лемківщина. - 1982. - Ч. 3. - С. 8.

4. Бородач В. Мартирологія українського Закерзоння / Василь Бородач // Лемківщина. - 1985. - Ч. 4. -

C. 14.

5. Гвозда I. др. Сучасна ситуація лемків у Польщі на тлі деяких історичних прикладів / др. Іван Гвозда // Лемківщина. - 1982. - Ч. 4. - С. 3-5.

6. Дорогі земляки, широка українська громадо! // Лемківщина. - 1979. - Ч. 1. - С. 1.

7. Ждинський Я. о. Спомин про виселення / о. Ярослав Ждинський // Лемківщина. - 1982. - Ч. 2. C. 26.

8. ІЛ. Ще до 40-річчя ганебного злочину в Закерзонні / ІЛ // Лемківщина. - 1987. - Ч. 3. - С. 2.

9. Крук Б. д-р. 40-ліття переселеної акції лемків (доповідь виголошена 17-го травня 1987 р. на Академії з нагоди 40-ліття виселення українців з їхніх прадідівських земель, яку влаштував 3-й відділ ООЛ) / д-р. Богдан Крук // Лемківщина. - 1987. - Ч. 2. - С. 2-5.

10. Лемківський Б. 1944 - 1947: Лемківщина терпить - Лемківщина плаче / Борис Лемківський // Лемківщина. - 1991. - Ч. 1. - С. 23-25.

11. Лико І. Ще до питання - УПА і Лемківщина / Іван Лико // Лемківщина. - 1982. - Ч. 2. - С. 1.

12. Лопата П. Лемківська Голгофа (У 35-ліття насильного виселення лемків - 1947 року) / Павло Лопата // Лемківщина. - 1982. - Ч. 2. - С. 5-6.

13. Лопата П. Становище лемків та їхня боротьба в Польщі на початку 30-их рр. XX століття / Павло Лопата // Лемківщина. - 1983. - Ч. 4. - С. 3-4.

14. Мицьо К. Роковини великої трагедії / Катерина Мицьо // Лемківщина. - 1981. - Ч. 2. - С. 10-11.

15. Міхнік А. Сенат про акцію «Вісла» / Адам Міхнік // Лемківщина. - 1990. - Ч. 4. - С. 5.

16. Назаревич Я. Дні жалоби й протесту в Торонті / Назаревич Ярослав // Лемківщина. - 1983. - Ч. 2. C. $2-3$.

17. Наконечний В. Журнал «Лемківщина»: ідейні засади, рубрикація, проблематика / Володимир Наконечний // Переяславський літопис: збірник наукових статей. - Переяслав-Хмельницький, 2016. - Вип. 10. C. 61-69.

18. Пасічняк В. Лемківщина - західний бастіон України / Василь Пасічняк // Лемківщина. - 1982. Ч. 3. - C. 4 .

19. Польський сенат засудив акцію «Вісла» // Лемківщина. - 1990. - Ч. 3. - С. 19.

20. Присутній. Відзначення 35-ліття вигнання лемків // Лемківщина. - 1982. - Ч. 3. - С. 9.

21. Саноцька Ю. Остання спільна молитва / Юлія Саноцька // Лемківщина. - 1982. - Ч. 2. - С. 4.

22. Феш М. (Рогач). На Лемківщині після виселення / Марта Феш (Рогач) // Лемківщина. - 1988. Ч. 1. - С. 16-19; Ч. 2. - С. 9-12.

23. Філь Я. (Марта). Мої спомини із Лемківщини / Ярослава (Марта) Філь // Лемківщина. - 1987. Ч. 4. - C. 4-7.

24. Ц Цяпка-Д. Г. Ще до 40-ліття ганьби / Грицько Цяпка-Д. // Лемківщина. - 1988. - Ч. 3. - С. 8-9.

25. Чи будемо готові? // Лемківщина. - 1987. - Ч. 1. - С. 2, 11.

26. Ще зацвітуть лани просторії... // Лемківщина. - 1987. - Ч. 2. - С. 1.

\section{REFERENCES}

1. 40 lit tomu... // Lemkivshchyna. - 1987. - Ch. 1. - S. 1.

2. Aktsiya «Visla» - Yak rozpaleno nenavyst'. Z istorykom Evhenom Misylom rozmovlyaye Zhenata Semprikh // Lemkivshchyna. - 1990. - Ch. 4. - S. 2-4.

3. Amerykans'ka presa 1948 roku pro trahediyu Zakerzonnya // Lemkivshchyna. - 1982. - Ch. 3. - S. 8.

4. Borodach V. Martyrolohiya ukrayins'koho Zakerzonnya / Vasyl' Borodach // Lemkivshchyna. - 1985. Ch. 4. - S. 14. 
5. Hvozda I. dr. Suchasna sytuatsiya lemkiv u Pol'shchi na tli deyakykh istorychnykh prykladiv / dr. Ivan Hvozda // Lemkivshchyna. - 1982. - Ch. 4. - S. 3-5.

6. Dorohi zemlyaky, shyroka ukrayins'ka hromado! // Lemkivshchyna. - 1979. - Ch. 1. - S. 1.

7. Zhdyns'kyy Ya. o. Spomyn pro vyselennya / o. Yaroslav Zhdyns'kyy // Lemkivshchyna. - 1982. - Ch. 2. -

S. 26.

8. IL. Shche do 40-richchya hanebnoho zlochynu v Zakerzonni / IL // Lemkivshchyna. - 1987. - Ch. 3. S. 2.

9. Kruk B. d-r. 40-littya pereselenoyi aktsiyi lemkiv (dopovid' vyholoshena 17-ho travnya 1987 r. na Akademiyi z nahody 40-littya vyselennya ukrayintsiv z yikhnikh pradidivs'kykh zemel', yaku vlashtuvav 3-y viddil OOL) / d-r. Bohdan Kruk // Lemkivshchyna. - 1987. - Ch. 2. - S. 2-5.

10. Lemkivs'kyy B. 1944 - 1947: Lemkivshchyna terpyt' - Lemkivshchyna plache / Borys Lemkivs'kyy // Lemkivshchyna. - 1991. - Ch. 1. - S. 23-25.

11. Lyko I. Shche do pytannya - UPA i Lemkivshchyna / Ivan Lyko // Lemkivshchyna. - 1982. - Ch. 2. - S. 1.

12. Lopata P. Lemkivs'ka Holhofa (U 35-littya nasyl'noho vyselennya lemkiv - 1947 roku) / Pavlo Lopata // Lemkivshchyna. - 1982. - Ch. 2. - S. 5-6.

13. Lopata P. Stanovyshche lemkiv ta yikhnya borot'ba v Pol'shchi na pochatku 30-ykh rr. XX stolittya / Pavlo Lopata // Lemkivshchyna. - 1983. - Ch. 4. - S. 3-4.

14. Myts'o K. Rokovyny velykoyi trahediyi / Kateryna Myts'o // Lemkivshchyna. - 1981. - Ch. 2. - S. 10-11.

15. Mikhnik A. Senat pro aktsiyu «Visla» / Adam Mikhnik // Lemkivshchyna. - 1990. - Ch. 4. - S. 5.

16. Nazarevych Ya. Dni zhaloby y protestu v Toronti / Nazarevych Yaroslav // Lemkivshchyna. - 1983. Ch. 2. - S. 2-3.

17. Nakonechnyy V. Zhurnal «Lemkivshchyna»: ideyni zasady, rubrykatsiya, problematyka / Volodymyr Nakonechnyy // Pereyaslavs'kyy litopys: zbirnyk naukovykh statey. - Pereyaslav-Khmel'nyts'kyy, 2016. Vyp. 10. - S. 61-69.

18. Pasichnyak V. Lemkivshchyna - zakhidnyy bastion Ukrayiny / Vasyl' Pasichnyak // Lemkivshchyna. 1982. - Ch. 3. - S. 4.

19. Pol's'kyy senat zasudyv aktsiyu «Visla» // Lemkivshchyna. - 1990. - Ch. 3. - S. 19.

20. Prysutniy. Vidznachennya 35-littya vyhnannya lemkiv // Lemkivshchyna. - 1982. - Ch. 3. - S. 9.

21. Sanots'ka Yu. Ostannya spil'na molytva / Yuliya Sanots'ka // Lemkivshchyna. - 1982. - Ch. 2. - S. 4.

22. Fesh M. (Rohach). Na Lemkivshchyni pislya vyselennya / Marta Fesh (Rohach) // Lemkivshchyna. 1988. - Ch. 1. - S. 16-19; Ch. 2. - S. 9-12.

23. Fil' Ya. (Marta). Moyi spomyny iz Lemkivshchyny / Yaroslava (Marta) Fil'// Lemkivshchyna. - 1987. Ch. 4. - S. 4-7.

24. Tsyapka-D. H. Shche do 40-littya han'by / Hryts'ko Tsyapka-D. // Lemkivshchyna. - 1988. - Ch. 3. S. 8-9.

25. Chy budemo hotovi? // Lemkivshchyna. - 1987. - Ch. 1. - S. 2, 11.

26. Shche zatsvitut' lany prostoriyi... // Lemkivshchyna. - 1987. - Ch. 2. - S. 1.

Стаття надійшла до редакиії 15.08.2017 p. 